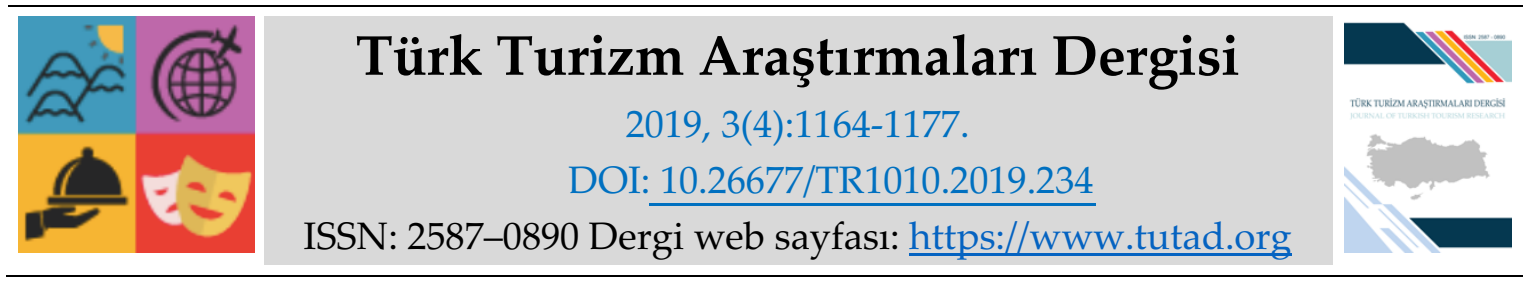

ARASTTIRMA MAKALESI

\title{
Üniversite Öğrencilerinin Kültürel Miras Farkındalığı ve Deneyimleri: Harran Üniversitesi Örneği- Şanlıurfa
}

Dr. Öğr. Üyesi Ali Rıza MANCI, Harran Üniversitesi, Turizm ve Otel İşletmeciliği Yüksekokulu, e-posta: armanci@harran.edu.tr ORCID: https://orcid.org/0000-0003-4618-5891

Öz

Mevcut kültürel miras unsurlarını gelecek kuşaklara aktarılabilmenin önemi tartışmasızdır. Bunun sağlanabilmesi için kültürel mirasın farkında olunması, deneyimlenmesi ve ne anlama geldiğinin bilinmesinin gerekli olduğu düşünülmektedir. Çalışmanın amacı, üniversite öğrencilerinin kültürel miras farkındalığı ve deneyimlerinin belirlenmesidir. Bunun için Harran Üniversitesi öğrencileriyle 445 anket gerçekleştirilmiştir. Hipotezlerin sınanması için MannWhitney U ve Kruskal-Wallis testleri yapılmıştır. Sonuç olarak, Soğmatar, Şuayp Antik Kenti, Rumkale, Karacadağ Kayak Merkezi, Ceylanpınar, Han el Bağrur, Bazda Mağaraları ve Mevlidi Halil Mağarası düşük; Hayati Harrani, Harran Harabeleri, Karaali Kaplıcası, Birecik Kelaynak orta; Göbekli Tepe, Balıklıgöl, Urfa Kalesi, Eyüp Nebi, Eyüp Peygamber Makamı, Şanlıurfa Müzesi, Haleplibahçe Mozaikleri, Tarihi Hanlar, Çarşılar ve Sokaklar, Atatürk Barajı ve Halfeti Cittaslow Saklı Kentin yüksek farkındalık ve deneyim düzeyine sahip olduğu gözlenmiştir. Öğrencilerin bölümlerinin, kişisel gelirlerinin ve memleketlerinin farkındalık ve deneyim düzeyinde etkili olduğu görülmüştür. Gelecek çalışmaların öznesi olarak yerel halkın alınması, soyut kültürel miras üzerinde de benzer çalışmaların yapılması önerilmiştir.

Anahtar Kelimeler: Farkındalık, Deneyim, Kültürel Miras, Şanlıurfa.

Makale Gönderme Tarihi: 21.02.2019

Makale Kabul Tarihi: 01.10.2019

\section{Önerilen Atıf:}

Mancı, A. R. (2019). Üniversite Öğrencilerinin Kültürel Miras Farkındalığı ve Deneyimleri: Harran Üniversitesi Örneği- Şanlıurfa, Türk Turizm Araştırmaları Dergisi, 3(4): 1164-1177.

(C) 2019 Türk Turizm Araştırmaları Dergisi. 


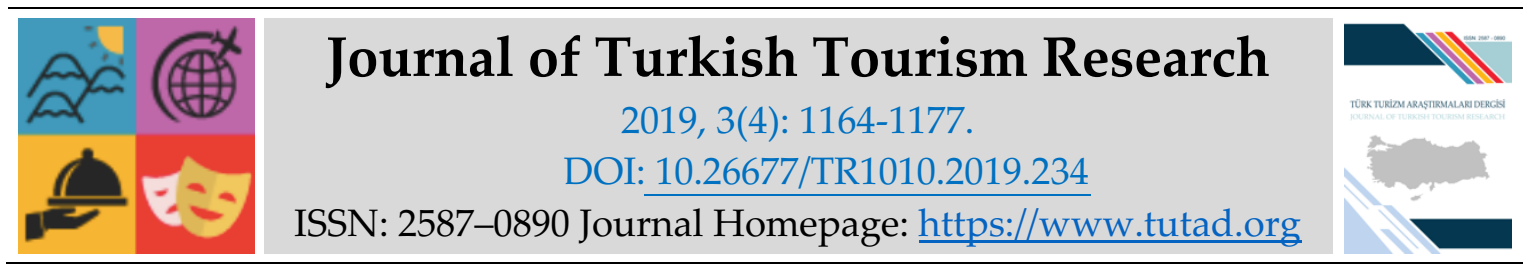

\title{
RESEARCH PAPER
}

\section{Heritage Awareness and Experience of University Students: An Example of Harran University-Şanlıurfa}

Dr. Ali Riza MANCI, Harran University, School of Tourism and Hotel Management, e-mail: armanci@harran.edu.tr

ORCID: https://orcid.org/0000-0003-4618-5891

\begin{abstract}
The importance of transferring existing cultural heritage elements to future generations is indisputable. In order to achieve this, it is necessary to be aware of and experience the cultural heritage and to know what these experiences mean. The aim of this study is to determine the cultural heritage awareness and experiences of university students. 445 surveys were conducted with Harran University students. Mann-Whitney U and Kruskal-Wallis tests were performed to test hypotheses. As a result, Soğmatar, the ancient city of Şuayp, Rumkale, Karacadağ ski center, Ceylanpınar, Han el Bağrur, Bazda caves and Mevlidi Halil cave are low; Hayati Harrani, Harran Ruins, Karaali thermal spring, Birecik kelaynak middle; Göbekli Tepe, Balıklıgöl, Urfa Castle, Eyüp Nebi, Eyüp Prophet, Şanlıurfa Museum, Haleplibahçe Mosaics, Historical inns, bazaars and streets, Atatürk Dam and Halfeti Cittaslow City have high level of awareness and experience. It was determined that the students' departments, personal incomes and hometowns were effective in their awareness and experience level. It was proposed to take the local population as the subject of future studies and to conduct similar studies on the intangible cultural heritage.
\end{abstract}

Keywords: Awareness, Experience, Cultural Heritage, Şanlıurfa

Received: 21.02.2019

Accepted: 01.10.2019

\section{Suggested Citation:}

Mancl, A. R. (2019). Heritage Awareness and Experience of University Students: An Example of Harran University-Şanlıurfa, Journal of Turkish Tourism Research, 3(4): 1164-1177.

(c) 2019 Türk Turizm Araştırmaları Dergisi. 


\section{Gíriş}

Kültür, bir toplumun ya da toplumların birikimli uygarlığı olarak tanımlanmaktadır (Çetin, 2014: 257). Kültürel miras ise; "geçmişten miras alınan ve değişik gerekçelerle geleceğe miras bırakılmak istenen, fiziksel olarak varlığı olan veya olmayan ve insanlar tarafından yapılmış her türlü eser ile bir topluma ait değerler bütünüdür" (Can, 2009: 3). Kültürel miras, somut ve somut olmayan olarak iki şekilde sınıflandırılmaktadır. Tarihi binalar, anıtlar, arkeolojik eserler, ören yerleri kısaca insan eliyle yapılmış her türlü nesneler somut kültürel miras olarak isimlendirilmektedir. Buna karşın, maddi olmayan kültür unsurları sözlü gelenek ve anlatımlar, dil, gösteri sanatları, toplumsal uygulamalar, ritüeller, şölenler, festivaller, doğa ve evrenle ilgili bilgi ve uygulamalar vb. (Can, 2009) somut olmayan kültürel miras sinıflandırılmasına dahil edilmektedir. Bu çeşit kültür çekicilikleri görmek, tanımak, bilmek ve deneyimlemek isteyen gezginler kültür turizmini canlandırmaktadır.

Dünya' da kültür turizminin payı gittikçe artmaktadır. Dolayısıyla gerek ülkeler gerekse kentler bu gelişimden pay almak için çaba sarf etmektedirler. Kentler sahip oldukları kültürel çekicilikleri çeşitli pazarlama yöntemleriyle kamuoyuna arz etmektedirler. Pazarlama yollarından biri de kentlerde öğrenim görmekte olan öğrenciler kanalıyla istenilen hedef pazara kolayca ulaşılabilmektir. Bu bağlamda, hali hazırdaki öğrencilerin kültürel değerlere yönelik farkındalıklarını ve deneyimlerini saptamak ilgili kent açısından önemli sayılabilir. Ayrıca kültürel mirasın korunarak gelecek kuşaklara aktarılmasının dolayısıyla sürdürülebilirliğinin sağlanabilmesinin en etkili yolunun miras unsurlarına olan farkındalık düzeyinin yükseltilmesi olduğu açıktır. Çünkü farkında olunmayan değerler sahiplenilmezler; zamanla aşınmaya, yozlaşmaya ve tahribata uğrarlar (Akkuş, Karaca ve Polat, 2015).

Nitekim literatürde konu hakkında birçok çalışma yapılmış olup, öğrenci kesiminin farkındalık düzeylerini belirlemek amaçlanmıştır (Uslu ve Kiper, 2006; Göğebakan, 2009; Çetin, 2010; Yeşilbursa, 2011; Arıkan, 2012; Çetin, Karakuş ve Aksoy, 2012; Del Barrio, Devesa ve Herrero, 2012; Seyhan, 2014; Demirbulat Güdü, Saatcı ve Avcıkurt, 2015; Ismail ve Nadarajah, 2016; Güneş ve Alagöz, 2018). Kültürel miras alanında zengin bir kent olan Şanlıurfa'nın kimi toplum kesimlerini (yerel halk, öğretmenler, öğrenciler, yöneticiler vb.) hedef alan araştırmaların keza kentin üniversitesinde okuyan öğrencileri konu edinen bir çalışmanın olmayışı nedeniyle literatürde bir boşluk olduğu değerlendirilmiş olup; çalışma sonucunda eksikliğin giderilebileceği öngörülmüştür.

Çalışmanın amacı, Harran Üniversitesinde öğrenim gören öğrencilerin yaşadıkları kent olan Şanlıurfa'nın tarihi ve kültürel değerlerine yönelik farkındalıklarını ve deneyimlerini tespit etmektir. İleriki yıllarda meslek sahibi olacak öğrenciler kentin elçisi konumuna gelebilir. Buradan hareketle, ağızdan ağıza pazarlama kanalıyla kentin sahip olduğu tarihi ve kültürel değerler öğrenciler vasıtasıyla yayılabilir. Dolayısıyla farkındalıkları ve deneyimlerinin belirlenmesi yapılacak pazarlama faaliyetlerine yol gösterici olacaktır. Aynı zamanda ilgili konunun araştırılmasını önemli kılmaktadır. Çalışmada aşağıdaki hipotezler oluşturulmuş, kültürel miras farkındalıkları ve deneyimlerin yerli ve yabancı ögrenciler arasında farklılıkları olabileceği sınanmaya çalışılmıştır. Aynı şekilde öğrencilerin bulundukları fakültelere ve kişisel gelirlerine göre farkındalık ve deneyimlerinin değişebileceği hipotezi ileri sürülmüsstür.

H1a: Katılımcıların kültürel miras farkındalıkları memleketlerine göre anlamlı farklılık göstermektedir.

H1b: Katılımcıların kültürel miras deneyimleri memleketlerine göre anlamlı farklılık göstermektedir.

H2a: Katılımcıların kültürel miras farkındalıkları öğrenim gördükleri fakültelere göre anlamlı farklılık göstermektedir. 
H2b: Katılımcıların kültürel miras deneyimleri öğrenim gördükleri fakültelere göre anlamlı farklılık göstermektedir.

H3a: Katılımcıların kültürel miras farkındalıkları kişisel gelirlerine göre anlamlı farklılık göstermektedir.

H3b: Katılımciların kültürel miras deneyimleri kişisel gelirlerine göre anlamlı farklılık göstermektedir.

\section{KAVRAMSAL ÇERÇEVE}

Kültürel miras, UNESCO'nun tanımıyla "daha önceki kuşaklar tarafından oluşturulmuş ve evrensel değerlere sahip olduğuna inanılan eserler, dil, kültür gibi yaşanmışlıklardan günümüze kalanlara verilen genel bir isimdir" (Açıc1, Ertaş ve Sönmez, 2017: 54). Günümüze kadar gelmiş bu çeşit varlıkların korunarak gelecek nesillere aktarılması noktasında literatürde görüş birliği oluşmuştur (Demirbulat Güdü vd., 2015; Yılmaz Karaca, Şahbudak, Akkuş ve Işkın, 2017) Nitekim (Külcü, 2015), kültürel mirası koruma politikaları arkeoloji ve kültür politikaları içinde çözülemediğini bu nedenle, genç yaştan itibaren bilinç kazandırılması gerektiğini belirtmiştir. Kültürel mirasın korunmasının etkili yollarından birinin toplumsal farkındalık olduğunu ileri sürülmektedir (Yılmaz Karaca vd., 2017).

Araştırmanın konusu kültürel miras değerlerine yönelik farkındalık düzeyinin ve deneyimlerinin tespitidir. Literatürde benzer çalışmaların farklı paydaşlar baz alınarak gerçekleştirildiği görülmektedir. Örneğin ilköğretim okulu öğrencileri (Gümüş ve Özüpekçe, 2009), turist rehberleri (Köroğlu, Ulusoy Yıldırım ve Avcıkurt, 2018), yerel halk (Vatan ve Zengin, 2015), öğretmen adayları (Gürgil, 2017), üniversite öğrencileri (Çetin ve Gürgil, 2014; Akkuş vd., 2015) turizm eğitimi alan öğrencilerin kültürel miras tutumları (Güneş ve Alagöz, 2018). Çalışmaların ortak özelliği halen öğrenim görmekte olan öğrencilerin ve yerel halkın kültürel miras farkındalık düzeylerinin yükseltilmesi sonucu korunarak gelecek nesillere kolaylıkla aktarılabileceği kuramına dayanmasıdır. Kurama göre, genç kuşakların kültürel miras unsurlarını sahiplenmesi, deneyimlemesi sürdürülebilirliği sağlamada etkili bir yöntemdir. Hatta toplum tarafından sahiplenilmeyen varlıkların kötü kullanım sebebiyle yok olacağı ya da tahrip edilebileceği (Yılmaz Karaca vd., 2017) üzerinde durulmaktadır.

Bu araştırmalara ek olarak, kültürel miras alan yönetimi paydaşları (Aysu, 2013), bilgi bilişim teknolojileri kullanılarak kültürel miras değerleri merkezli “Değer Tabanlı Kültürel Miras Karar Destek Modeli" önerisi (Korumaz, 2015), kültürel mirasın üç boyutlu modellenmesi ve web ortamında sunulması (Ahmet Uslu, 2016) vb. benzer çalışmalar içerisinde sayılabilir.

Selçuk (1999: 258), "öğrencilerimiz, kültürel mirası değerlendirsin, eleştirsin, geliştirsin mi, yoksa onu destanlaştırsın $m \imath$ " cümlesiyle şekilden ziyade içeriğin önemli olduğunu vurgulayarak kültürel mirasa farklı bir bakış açısı getirmektedir. Benzer şekilde, Koç ve Akdoğan (2018), asıl olanın kimi anıtsal mekanların deneyimlemek olmadığını, bu çeşit kültürel miras öğelerinde içkin bulunan bazı değerlerin örneğin toplu yaşama, iş birliği, sosyalleşme, yardımlaşma, toplumsal sorumluluk, dış tehditlere karşı birlikte korunma, sabırlı olma, inanç, paylaşımcı olma, şiddetten kaçınma, hoşgörü vb. değerlerin gelecek kuşaklara aktarılabilmesi olduğunu vurgulamaktadirlar.

"Kültürel turizm sadece mekân ve anıtlarn ziyareti değil, ziyaret edilen alanlardaki yaşam tarzının da öğrenilmesini içermektedir" görüşü önceki çalışmaların ana fikirleriyle örtüşmektedir. (Çetin ve Gürgil, 2014: 3). Ayrıca aynı araştırmada turizm, kültür, kültür turizmi, farkında olma kavramlarının literatürdeki anlamları verilerek bir kavramsal çerçeve oluşturulmuştur. Kavramsal çerçeven yola çıkarak üniversite öğrencilerinin doğal ve kültürel turizm değerlerine 
yönelik farkındalıkları tespit edilmeye çalışılmıştır (Çetin ve Gürgil, 2014). Demirbulat Güdü vd. (2015), Bursa ilinin kültürel varlıklarına yönelik öğrencilerin algılarını belirlemek amacıyla 36 ifade kullanılmış, istatistiksel olarak anlamlı bulgulara ulaşılmış, koruma-kullanma dengesinin gözetilmesi ve bu tür çalışmaların belirli aralıklarla tekrarlanmasını önermişlerdir.

Uluslararası literatürde benzeri çalışmalara da rastlanmaktadır (Aplin, 2007; Hovater, 2007; Vehbi ve Hoşkara, 2009; Nicholas, Thapa ve Ko, 2009; Akinlabi, 2011; Jimura, 2011; Jaafar, Noor ve Rasoolimanesh, 2015; Srivastava, 2015; Adeniran ve Durak, Yeke ve Arslan, 2016; Ismail ve Nadarajah, 2016; Abdelazim Ahmed, 2017).

\section{YÖNTEM}

Araştırmanın amacı, Harran Üniversitesinde öğrenimine devam etmekte olan öğrencilerin Şanlıurfa'nın kültürel miras değerlerine olan farkındalık düzeylerini ve deneyimlerini belirlemektir. Bu amacı gerçekleştirmek için öğrencilerle yüz yüze anket yapılmıştır. Anketin ilk bölümünde demografik özellikler sorulmuştur. İkinci bölümünde öğrencilerin Şanlıurfa'nın kültürel miras çekiciliklerinin farkındalığını tespit etmek maksadıyla 3'lü Likert yöntemi kullanılmıştır. Üçüncü bölümde ise, çekicilikler karşısındaki deneyimleri ilgili yerleri ziyaret edip etmedikleri yine 3'lü Likert ölçeği kullanarak ölçülmeye çalışılmıştır. Likert ölçeğindeki maddeler Akkuş vd., (2015)'nin çalışmasından Şanlıurfa'ya uyarlanarak oluşturulmuştur. İfadeler il kültür turizm müdürlügünün web sayfasında bulunan somut kültür envanterinden yararlanılarak derlenmiştir. Farkındalık düzeyi tutumlarını ölçmek için 1- Bilmiyorum, 2- Az çok biliyorum, 3- Biliyorum, aynı ifadeler ziyaret deneyimi açsından 1- Gitmedim, 2- Ara sıra giderim 3- Gittim şeklinde rakamsal olarak kodlanmıştır. Ölçeklerin hepsinin Cronbach alfa güvenirlilik katsayısı 0,95 ve üzerinde olduğu görülmüştür. Ölçeklerin iç tutarlılı̆̆ yüksek düzeyde olduğu tespit edilmiş, dolayısıyla ölçeklerden güvenilir veriler elde edilmiştir.

Araştırmanın evrenini Harran üniversitesinde öğrenim görmekte olan öğrenciler oluşturmaktadır. Çeşitli fakülte ve yüksekokullarda anket çalışması yapılmıştır. Fakülteler arasında İ̈BF, mühendislik, eğitim, ziraat, fen-edebiyat, tıp, BESYO, Turizm MYO, veteriner ve ilahiyat bulunmaktadır. Diğer fakültelerle kıyaslama yapabilmek ve farkındalık/deneyim düzeylerinin yüksek çıkması beklentisinden dolayı özellikle Turizm MYO öğrencilerinden de veri toplanmaya çalışılmıştır. Evren büyüklügünü Harran Üniversitesi öğrenci sayısı oluşturmaktadır; sayı yaklaşık 25,000'dir. Kolayda örnekleme yöntemiyle 445 adet anket yapılmışır. \%95 güven aralığında, \%5 hata payı öngörülerek yapılan araştırmalarda yeterli örneklem büyüklüğünün 381 adet olması yeterli görülmektedir (Kozak, 2015: 113).

Öğrencilere Şanlıurfa'da mevcut hangi tarihi yerleri biliyorsunuz sorusu yöneltilmiştir. İlgili yerleri ziyaret edip etmedikleri sorularak deneyimleri ölçümlenmeye çalışılmıştır. Verilerin daha sağlıklı elde edilmesi amacıyla anketlerin yüz yüze olmasına önem verilmiştir. Verilerin analizinde Mann-Whitney $U$ ve Kruskal-Wallis testi kullanılmıştır. Farklılıkların hangi değişkenlerden kaynaklandığını tespit etmek için ortalama sıralama (Mean Rank) kullanılmıştır. Testlerin gerçekleştirilmesinde SPSS 25.0 istatistik programından yararlanılmıştır.

\section{Araştırma Alanı ile İlgili Genel Bilgiler}

Şanlıurfa birçok medeniyete ev sahipliği yapmış kadim bir şehirdir. Arkeoloji tarihine "Balıklıgöl Heykeli" olarak kaydettirilen, "Dünyanın En Eski Heykeli" kentte bulunmuştur. Böylece Urfa kent merkezinin MÖ.10000'e, Neolitik Döneme, kadar uzanan bir yerleşim alanı olduğu bir kez daha teyit edilmiştir. Ebla, Akkad, Sümer, Babil, Hitit, Hurri-Mitanni, Arami, 
Asur, Pers, Makedonya, Roma, Bizans gibi uygarlıkların egemenliklerini gören Urfa, 639'dan sonra İslam'la tanışmıştır. 1094 yılında Selçuklu topraklarına katılan şehir, 1098'de Haçlı Kontluğu idaresine girmiştir. Eyyubi, Memluk, Türkmen aşiretleri, Timur Devleti, Akkoyunlular, Dulkadirbeyliği, Safeviler iktidarlığını gören Urfa, 1516'da Osmanlı Devleti sınırları içine dâhil edilmiştir. İlk olarak Diyarbakır Eyaleti'ne bağlanan şehir, 1876'da Halep Vilayetine bağlanmıştır. Eski ismi Edessa olan Urfa'nın, isminin Urhai, Orhai, Ruha vb. isimlerden geldiği söylenmektedir (Şanlıurfa İl Kültür Müdürlüğü, 2018).

Şehirde somut ya da somut olmayan sayısız kültürel miras varlıkları kayıt altına alınmaya çalışılmaktadır. Ayrıca geniş yemek ve müzik kültürü, el sanatları ve halk kültürüne sahip şehir, son yıllarda keşfedilen antik Göbekli Tepe kalıntıları ile gündeme gelmiştir. Çalışmada ele alınan kimi kültürel miras varlıkları esasen Göbekli Tepe kadar tarihi ve kültürel sahada anlamlı olarak kabul edilebilir. Bunlar arasında, antik Sogmatar Kenti, Zeugma Mozaikleri'nden daha nitelikli kabul edilen Haleplibahçe Mozaikleri, kimi peygamberlerin yaşadığı varsayılan Şuayb Şehri, Hz. İbrahim'in ateşe atıldığı yer olarak söylenilen Balıklıgöl ve dünyanın ilk üniversitesinin kurulduğu, konik kerpiç evleri ile dikkat çeken Harran Harabeleri sayılabilir. Kaya Mezarları, Bazda Mağaraları, Han el Bağrur Kervansarayı, Urfa Kalesi, Şanlıurfa Müzesi, Eyüp Peygamber Makamı, Halfeti Cittaslow Saklı Kenti, az bilinen Karacadağ Kayak Merkezi bunlar arasına eklenebilir.

Kentin kültürel değerlerinin ayrıntılı şekilde sunulması çalışmanın kapsamında olmadığından il kültür turizm ve ŞURKAV (Şanlıurfa ili Kültür Eğitim Sanat ve Araştırma Vakfı) web adresleri ziyaret edilerek yeterli bilgi elde edilebilir (Şanllurfa İl Kültür Müdürlüğü ve ŞURKAV, 2018).

\section{ARAŞTIRMA BULGULARI ve TARTIŞMA}

Harran Üniversitesinin çeşitli bölümlerinde öğrenim görmekte olan öğrencilerle yüz yüze anketler yapılarak çeşitli veriler elde edilmiştir. Verilerin güvenilir olduğu sınama sonucu anlaşılmıştır. Uygun istatistiki analizler yapılarak kimi bulgulara ulaşılmıştır.

$\mathrm{Bu}$ bölümde, öğrencilerin Şanlıurfa'nın kültürel miras değerlerine ilişkin farkındalık ve deneyim düzeyleri çeşitli değişkenler açısından değerlendirilmiştir. Araştırma bulguları tablolar şeklinde ifade edilmiştir. Önceki çalışmaların bulgularıyla karşılaştırılarak tartışılmıştır.

\section{Araştırma Bulguları}

Katılımcılara yöneltilen ifadeler için yapılan güvenirlik analizi sonucunda Cronbach's Alpha katsayısı hesaplanmış, oldukça yüksek bir katsayı elde edilmiştir. Genellikle 0,80<1,00 yüksek derecede güvenilir yorumu yapılır. Buna göre, ifadelerin güvenirliliği yüksek düzeydedir (Tablo 1).

Tablo 1. SPSS Programına Aktarılan Verilerin Güvenirlik Katsayıları

\begin{tabular}{l|l|r}
\hline Bilgiler & Cronbach's Alpha & Ífade sayısı \\
\hline Farkındalık düzeyi & 0,950 & 24 \\
Deneyim & 0,963 & 24 \\
\hline
\end{tabular}

Katılımcıların farkındalık ve deneyimlerinin aritmetik ortalaması 1 ile 1.75 arası düşük, 1.762.25 orta, 2.26 ve üstü yüksek farkındalık ve deneyim düzeyi şeklinde yorumlandığında, 
Nevaliçöri, Soğmatar, Şuayp Antik Kenti, Rumkale, Karacadağ Kayak Merkezi, Ceylanpınar, Han el Bağrur, Bazda Mağaraları ve Mevlidi Halil Mağarası düşük; Hayati Harrani, Harran Harabeleri, Karaali Kaplıcası, Birecik Kelaynak orta; Göbekli Tepe, Balıklıgöl, Urfa Kalesi, Eyüp Nebi, Eyüp Peygamber Makamı, Şanlıurfa Müzesi, Haleplibahçe Mozaikleri, Tarihi hanlar, çarşılar ve sokaklar, Atatürk Barajı ve Halfeti Cittaslow Saklı Kent'in yüksek farkındalık ve deneyim düzeyine sahip olduğu gözlenmiştir. Göbeli Tepe son yıllarda gözde uğrak bir mekân olduğundan yüksek deneyim seviyesindedir. Keza Balıklıgöl ve Urfa Kalesi çok ziyaret edilen yerler arasında sayılabilir. Mevlidi Halil mağarasının da çok bilinen ve ziyaret edilen bir yer olmasına karşın genellikle Hz. İbrahim Dergâhı olarak isimlendirildiğinden dolayı aritmetik ortalaması düşük düzeyde gözlendiği tahmin edilmektedir.

Tablo 2. Kültürel Miras Farkındalık ve Deneyimine Ait Ortalama, Standart Sapma Değerleri

\begin{tabular}{|c|c|c|c|c|}
\hline & 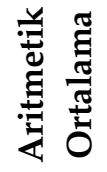 & 㽕 & 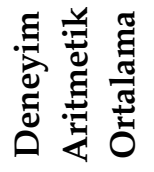 & సีّ \\
\hline Nevaliçöri & 1,51 & 804 & 1,59 & 790 \\
\hline Göbeklitepe & 2,33 & 785 & 2,32 & ,822 \\
\hline Harran Harabeleri & 2,19 & 841 & 2,28 & ,824 \\
\hline Soğmatar & 1,68 & 861 & 1,93 & ,826 \\
\hline Şuayp Antik Şehri & 1,73 & 842 & 1,93 & ,834 \\
\hline Balıklıgöl & 2,65 & 718 & 2,71 & 630 \\
\hline Urfa Kalesi & 2,67 & 695 & 2,74 &, 598 \\
\hline Eyüp Nebi & 2,49 & ,815 & 2,55 & 754 \\
\hline Eyüp Peygamber Makamı & 2,59 & 753 & 2,64 & 699 \\
\hline Şanlıurfa Müzesi & 2,56 & 783 & 2,57 & 740 \\
\hline Haleplibahçe Mozaikleri & 2,30 & 891 & 2,40 & ,815 \\
\hline Tarihi hanlar, çarşılar ve sokaklar & 2,48 & 787 & 2,59 & 741 \\
\hline Atatürk Barajı & 2,36 & ,858 & 2,44 & 813 \\
\hline Karaali Kaplıcası & 2,10 & ,924 & 2,17 & 821 \\
\hline Hayati Harrani & 1,99 & 897 & 2,15 & 811 \\
\hline Halfeti Cittaslow Saklı Kent & 2,28 & ,885 & 2,31 & 819 \\
\hline Birecik Kelaynak & 2,05 & ,912 & 2,14 & ,818 \\
\hline Rumkale & 1,61 &, 846 & 1,93 & 812 \\
\hline Karacadağ Kayak Merkezi & 1,71 & 887 & 1,82 & 803 \\
\hline Ceylanpinar & 1,52 & 815 & 1,79 & ,796 \\
\hline Han el Bağrur & 1,41 & 765 & 1,77 & ,763 \\
\hline Bazda Mağaraları & 1,46 & 789 & 1,79 & 803 \\
\hline Mevlidi Halil Mağarası & 1,63 & 873 & 1,91 & 792 \\
\hline Reji Kilisesi & 1,87 & ,954 & 1,82 & ,856 \\
\hline
\end{tabular}

Katılımcıların kişisel özellikleri tablo 2'de özetlenmiştir. Katılımcıların yarısı kadın yarısı erkektir. Yaş aralığı beklendiği gibi 18-24 arası yoğunlaşmıştır. Katılımcıların önemli bir kısmı yabancı olarak adlandırılan Şanlıurfa dışında ikamet etmekte olan öğrencilerdir $(\% 62,5)$. Yerli olarak ifade edilen katılımcılar ise Şanlıurfa' da ikamet edenlerden oluşmaktadır $(\% 37,5)$. Lisans öğrencileri katılımcıların \%86,3'ünü oluşturmaktadır. Ön lisans eğitim seviyesindeki 
katılımcılar turizm MYO öğrencileridir. Turizm öğrencilerinin özellikle çözümlemeye dahil edilmesinin nedeni farkındalık ve deneyim açısından diğer bölümlerdeki öğrencilerle arasında bir farklılık olup olmadığını ölçmektir. Eğitim seviyesi grupları halihazırda üniversitede okuyan öğrencilerin toplamı ile uyumlu oranda seçilmiş olduğu gözlenmektedir. Katılımcıların neredeyse tamamının bekar olması öğrenci olmalarının beklenen bir sonucudur. Öğrencilerin \%65,6'sının kişisel gelirler yani harçlıkları 1000 TL'nin altında olup, diğerlerinin ise 1000 TL'nin üzerindedir. Mühendislik, İÏBF ve Eğitim fakültesi öğrencileri örnekleme dahil edilen katılımcların \%53,2'sini oluştururken, yaklaşık \%10'unu ziraat fakültesindendir. Turizm MYO öğrencileri katılımcıların \%8,6'sına tekabül etmektedir. Üç yıldır Şanlıurfa'da ikamet etmekte olan katılımcılar toplamın \%43,4'ünü oluşturmaktadır. İkamet süresi bir yıldan az olanların oranı sadece $\% 5,8^{\prime}$ dir.

Elde edilen veriler normal dağılım göstermemektedir. Dolayısıyla katılımcıların ilgili yerler hakkında kültürel miras farkındalık düzeyleri ile memleketleri arasında farklılığı tespit etmek için parametrik olmayan Mann-Whitney u testi yapılmıştır. Test sonucunda analize dahil edilen kimi yerlerin katılımcıların memleketlerine göre farklılık gösterdiği gözlenmiştir. Bunlar sırasıyla Nevaliçöri, Göbekli Tepe, Harran Harabeleri, Sogmatar, Şuayb Antik Kenti, Eyüp Nebi, Eyüp Makamı, Atatürk Barajı, Karaali Kaplıcası, Hayati Harrani, Halfeti, Kelaynak, Rumkale, Karacadağ Kayak Merkezi, Ceylanpınar, Hanelbağrur, Bazda Mağaraları, Mevlidihalil Mağarası ve Reji Kilisesidir ( $\mathrm{p}<0,05)$. Şanlıurfa'lı olarak kendisini ifade eden yerli öğrencilerin yukarıda sayılan yerler hakkında farkındalık düzeyleri dışarıdan öğrenim görmek için gelenlerden daha yüksektir. İstatistiki olarak anlamlı bir fark bulunamayan kültürel miras çekicilikleri arasında ise, Balıklıgöl, Urfa Kalesi, Şanlıurfa Müzesi, Haleplibahçe Mozaikleri, Tarihi sokaklar ve çarşıları $(p>0,05)$ belirtilebilir. Şanlıurfalı öğrencilerin ile Şanlıurfalı olmayanların arasında farkındalık düzeyi açısından bir farklılık tespit edilememiştir.

Katılımcı öğrencilerin fakültelerine göre farkındalık düzeyleri arasında farklılık vardır hipotezini sınamak amacıyla yapılan Kruskal-Wallis testine göre, Nevaliçöri, Göbekli Tepe, Harran Harabeleri, Sogmatar, Şuayb Antik Kenti, Hayati Harrani, Halfeti, Kelaynak, Rumkale, Karacadağ Kayak Merkezi, Ceylanpınar, Hanelbağrur, Bazda mağaraları, Mevlidihalil mağarası ve Reji Kilisesi farklılık göstermiştir p $<0.05$. Bölümlerin ortalama sıralamasında (Mean Rank) beklentilerin tersine BESYO ardından Tip fakültesi öğrencilerinin en fazla değere sahip olduğu, buna karşın turizm MYO öğrencilerinin ikinci sırada, en az değeri alan bölümün ise mühendislik fakültesi olduğu bulgusuna ulaşılmıştır. Mühendislik öğrencilerinin teknik konulara daha fazla eğilimli olması onları sosyal, kültürel ortamlardan uzaklaştırabileceği şeklinde yorumlanabilir. Diğer taraftan Balıklıgöl, Urfa Kalesi, Şanlıurfa Müzesi, Haleplibahçe Mozaikleri, Tarihi sokaklar ve çarşılar ile bölümler arasında bir farklılık bulunamamıştır $p>0.05$.

Aynı yöntemle bu kez katılımcıların deneyimlerinin memleketlerine göre farklı olup olmadı̆̆ını tespit amacıyla Mann-Whitney U testi uygulanmış olup; Göbekli Tepe, Harran Harabeleri, Atatürk Barajı, Karaali Kaplıcası, Hayati Harrani, Halfeti, Kelaynak, Rumkale, Karacadağ Kayak Merkezi, Hanelbağrur, Bazda Mağaraları, Mevlidihalil Mağarası arasında farklılık bulunmuştur $\mathrm{p}<0.05$. Bu durumda, Şanlıurfa'da ikamet etmeyen katılımclların bu yerleri ziyaret etmesi hem uzaklıklarının hem de maddi imkanlarının kısıtlı olması sebebiyle olması ihtimal dahilindedir. Bunun için ilgili yerleri deneyimlemek yerel yönetimin maddi katkısı ile mümkün olabilir. Keza üniversitenin düzenleyeceği teknik gezi imkanlarıyla öğrenciler hafızalarından uzun yıllar silinemeyecek deneyimler elde edebilirler.

Fakültelere göre ise deneyimler sadece Haleplibahçe mozaiklerinde farklılık göstermemektedir. Diğer bütün yerlerde bölümlere göre deneyimler değişmektedir. Bölümlerin ortalama sıralamasında (Mean Rank) beklentilerin tersine eğitim fakültesi ardından Tıp fakültesi öğrencilerinin en fazla değere sahip olduğu, buna karşın, en az değeri alan bölümün ise Turizm 
MYO olduğu görülmüştür. Dolayısıyla turizm MYO öğrencilerinin birçok kültürel miras çekiciliklerinin farkında olduğu fakat deneyimlerinin olmadığı bulgusuna ulaşılmıştır.

Tablo 3. Katılımcılara Ait Demografik Bilgiler

\begin{tabular}{|c|c|c|c|}
\hline Bilgiler & Gruplar & Say1 & Yüzde \\
\hline \multirow{2}{*}{ Cinsiyet } & Erkek & 226 & 50,8 \\
\hline & Kadın & 219 & 49,2 \\
\hline & $18-24$ & 374 & 84,0 \\
\hline \multirow{2}{*}{ Yaş } & $25-34$ & 66 & 14,8 \\
\hline & 35 ve üstü & 5 & 1,1 \\
\hline \multirow[t]{3}{*}{ Memleket } & Yerli & 167 & 37,5 \\
\hline & Yabancı & 278 & 62,5 \\
\hline & Ön lisans & 48 & 10,8 \\
\hline \multirow[t]{2}{*}{ Eğitim } & Lisans & 384 & 86,3 \\
\hline & Lisansüstü & 13 & 2,9 \\
\hline \multirow[t]{3}{*}{ Medeni durum } & Evli & 29 & 6,5 \\
\hline & Bekar & 410 & 98,7 \\
\hline & $0-250$ & 13 & 2,9 \\
\hline \multirow{5}{*}{ Harçlık } & $251-500$ & 27 & 6,1 \\
\hline & $501-750$ & 216 & 48,5 \\
\hline & $751-1000$ & 36 & 8,1 \\
\hline & 1001 ve üzeri & 153 & 34,4 \\
\hline & 1 yıldan az & 26 & 5,8 \\
\hline \multirow[t]{5}{*}{ İkamet süresi } & $1 \mathrm{y} 1 \mathrm{l}$ & 15 & 3,4 \\
\hline & 2 yil & 87 & 19,6 \\
\hline & 3 yil & 193 & 43,4 \\
\hline & 4 yıl ve üstü & 124 & 27,9 \\
\hline & 1. sinif & 59 & 13,3 \\
\hline \multirow[t]{4}{*}{ Sinif } & 2. sinif & 109 & 24,5 \\
\hline & 3. sinif & 114 & 25,6 \\
\hline & 4. sinif & 132 & 29,7 \\
\hline & Uzatma & 31 & 7,0 \\
\hline \multirow[t]{9}{*}{ Fakülte } & Mühendislik & 90 & 20,3 \\
\hline & İ̈BF & 80 & 18,0 \\
\hline & Eğitim & 66 & 14,9 \\
\hline & Ziraat & 43 & 9,7 \\
\hline & Fen-Edebiyat & 37 & 8,3 \\
\hline & Tip & 23 & 5,2 \\
\hline & Besyo & 39 & 8,8 \\
\hline & Turizm MYO & 38 & 8,6 \\
\hline & İlahiyat & 28 & 6,3 \\
\hline \multirow[t]{6}{*}{ Aile Geliri } & $1000-1999$ & 144 & 32,4 \\
\hline & 2000-2999 & 120 & 27,0 \\
\hline & 3000-3999 & 110 & 24,7 \\
\hline & 4000-4999 & 53 & 11,9 \\
\hline & 5000 ve üstü & 18 & 4,0 \\
\hline & & 445 & 100 \\
\hline
\end{tabular}


Gelecekte turizm meslek erbabı olacak öğrencilerin yetersiz deneyim seviyesinde olması, bu konudaki eksikliğin acil olarak giderilmesi gerektiği sonucunu doğurmaktadır. Kendi kültürel miras değerlerini deneyimlememiş turizm öğrencilerinin mevcut değerleri yerli ve yabancı ziyaretçilere aktarması beklenemez. O halde, kültürel miras değerlerini ilk önce turizmle iştigal etmekte ya da edecek olan kişiler tarafından içselleştirilmesi gerekliliği yadsınamaz bir gerçektir. Kültürel miras değerlerinin sürdürülebilirliğinin sağlanması yalnızca farkındalık seviyesi, bilinçsiz deneyimlerle açıklanamaz. Bunun için, kültürel miras değerlerinin ne anlam ifade ettiğinin ziyaretçiler tarafından içselleştirilmesi gerektiği literatürde iddia edilmektedir. İçselleştirilememiş, anlamlandırılamamış, bugüne getirilememiş, sorgulanmamış ve eleştirilmemiş değerler kolayca unutulurlar. Halbuki sorgulamaya tabi tutulmuş olan değerler rahatlıkla sonraki kuşaklara miras olarak bırakılabilir (Selçuk, 1999).

Kişisel gelirleri analiz edildiğinde yukarıdaki bulguları destekler mahiyette bulgulara ulaşılmıştır. Farkındalık düzeyi ile katılımcıların kişisel gelirleri arasında Kruskal-Wallis sınaması ile sadece Eyüp Peygamber Makamı, Tarihi sokaklar ve çarşılar, Karaali Kaplıcası, Hayati Harrani, ve Kelaynak yerleri kişisel gelire göre farklılık göstermektedir. Katılımcıların deneyimleri ise, Göbekli Tepe ve Haleplibahçe Mozaikleri hariç tümünde kişisel gelire göre farklılık tespit edilememiş̧ir. Çünkü deneyim için harçlık gerekir dolayısıyla harçlığı kısıtlı olan öğrencilerin şehir merkezine uzak yerleri deneyimlemesi olası değildir. Bunun için maddi anlamda desteklenmeleri gerekir.

Çalışma, Harran Üniversitesi öğrencilerinin kültürel miras unsurlarına yönelik bilinirlik ve tecrübelerini ölçmek amacıyla hazırlanmıştır. Amaç çerçevesinde kimi hipotezler kurulmuş ve uygun istatistiki analizler yapılmıştır. Çalışma sonucunda muhtelif kültürel miras unsurlarının katılımcılarının yerli ve yabancı olup olmamasına, öğrenim görmekte oldukları bölümlere ve kişisel gelirlerine göre istatistiksel olarak anlamlı farklılık gösterdiği bulgularına ulaşılmıştır. Ayrıca bazı kültürel miras mekanlarının bilinirlilik ve deneyimlenmesinin çok düşük olduğu, bazılarının orta düzeyde, bazılarının ise yüksek düzeyde olduğu tespit edilmiştir. Fakat genel olarak, bilinirlik seviyesinin yeterli olmasına rağmen, deneyimlemenin çok gerilerde kaldığı anlaşılmıştır. Kültürel miras unsurlarına yönelik bilinirlik ve tecrübe çalışmalarının yerel halk, yerli turist, ilköğretim ve üniversite öğrencileri üzerine odaklandığı görülmektedir. Bu bölümde araştırmaların öznesi olarak seçilen öğrenciler üzerinde yapılan çalışmalar tartışılmaya çalışılmıştır. Örneğin Güneş ve Alagöz, 2018 çalışmanın bulgusuyla örtüşen bir şekilde öğrencilerin öğrenim gördükleri programa göre kültürel miras tutumlarının farklılık gösterdiğini belirtmektedir. Aşçılık programı öğrencilerinin bu yönde daha fazla ilgili oldukları öne çıktığını beyan etmişlerdir. Aynı şekilde, (Akkuş vd., 2015) farkındalık ve deneyim düzeylerinin öğrenim görülen bölüme göre kültürel çekiciliklerin tamamının olmasa bile, ekseriyeti için farklılık oluşturduğunu ileri sürmüşlerdir. Aynı bulguya (Çetin ve Gürgil, 2014)'de çalışmalarında ulaşmışlardır. Fakat Çetin ve Gürgil'e göre, Fen Bilgisi öğretmenliği öğrencileri, Bartın ilinin kültürel miras değerlerine ilgi düzeyleri diğer bölümlerle kıyaslandığında daha fazla ortalama değere sahiptir. Bu şekilde, çalışmanın bulgusuyla ters istikamette bir sonuca ulaşmışlardır. Bunun yanı sıra (Demirbulat Güdü vd., 2015) öğrencilerin Bursa'nın somut kültürel varlıklarına ait görüşlerinin bölümlerine göre farklılaşmadığını ortaya koymuşlardır. Halbuki öğrencilerin eğitim aldıkları programın kültürel miras algısında farklılık gösterdiği birçok çalışmada ortak bulgu olduğu gözlenmiştir (Dinç, Erdil ve Keçe, 2011; Çetin ve Gürgil, 2014). Bu çeşit farklı algıların oluşmasında öğrenim görülen bölümün içeriğine göre değişebileceği söylenebilir. Şöyle ki, genellikle sosyal içerikli dersler alan öğrencilerin farkındalık ve deneyim düzeyinin yüksek olması beklenen bir durumu yansıtmaktadır. Farkındalık ve deneyim düzeylerinin sınıflara göre farklılaştı̆̆ını belirten çalışmalar bulunmakla birlikte (Akkuş vd., 2015), somut kültürel varlıklara yönelik görüşlerde öğrenim 
görülen sınıfa göre bir farklılık bulunmadığını belirten çalışma da mevcuttur (Demirbulat Güdü vd., 2015).

Bununla birlikte, çalışmada elde edilen yerli katılımcıların farkındalık ve deneyim düzeyleri yabancılardan farklı olduğu bulgusuna koşut olarak (Akkuş vd., 2015) ve (Yılmaz Karaca vd., 2017)'nin çalışmalarında da Sivaslı olan öğrencilerin farkındalık ve deneyim ölçeği ortalamalarının Sivaslı olmayanlara göre daha yüksek olduğu tespit edilmiştir. Aynı şekilde memleketlerine göre farkındalık ve deneyim düzeyinin değiştiğini (Demirbulat Güdü vd., 2015) belirtmişlerdir. Bununla beraber, literatürde kültürel mirasın aslını muhafaza ederek gelecek nesillere aktarabilmenin en sağlıklı yönteminin, insanları bilinçlendirilerek farkındalık düzeylerinin yüksek tutulması olduğu konusunda görüş birliği bulunmaktadır (Simşek ve Elitok Kesici, 2012; Külcü, 2015; Durak vd., 2016; Richards, 2018).

2019 yılının Göbekli Tepe yılı olması dolayısıyla ziyaretçi sayısında belirgin bir artışın olacağı öngörülmektedir. Buna karşın kentin sahip olduğu diğer kültürel çekiciliklerin göz ardı edilebileceği kaygı yaratabilir. Böylece hızla artan turist akımı belirli bir süre sonra kesilebileceği yatırımların atıl kalabileceği riski ile karşılaşılabilir. Oysa bu ve benzeri çalışmaların sonuçları dikkate alındığında, ziyaretçilerin devamlılığının sağlanması için temelli, planlı ve sağlam adımlar atılması önerilmektedir. Hatta çocuklardan başlayarak kültürel mirasın yeni kuşaklara aktarımının yapılması sabırlı bir eğitim süreci olduğu vurgulanmaktadır.

Araştırma belirli bir bölgede yapılmıştır, sadece öğrencilerin görüşlerini yansıtmaktadır. Bunun için sonuçlarının genelleştirilmesi olası değildir. Bu da çalışmanın sınırlılıkları arasında sayılabilir.

\section{SONUÇ ve ÖNERILER}

Mevcut kültürel mirasın değerlendirilip ileri aşamalara taşıma kararlılığı gösterebilmek için öncelikle içinde bulunulan kültürel mirasın farkına varmak gerekli olup, kültürel ortamını bizzat teneffüs etmek yani deneyimlemek icap eder. Bir başka ifade ile kültürel miras değerlerinin anlamlarını içselleştirmek sürdürülebilirliği açısından önemlidir. Çalışma neticesinde öğrencilerin farkındalık düzeyleri ve deneyimlerinin kimi kültürel miras değerleri konusunda düşük düzeyde olduğu sonucuna ulaşılmıştır. Ayrıca öğrencilerin farkındalık ve deneyim düzeylerinin memleketlerine, kişisel gelirlerine ve bölümlerine göre değiştiği tespit edilmiştir. Çalışmanın sonucunda kimi kültürel miras unsurlarının öğrenciler tarafından bilinmediği, bilinenlerin de ziyaret edilmediği sonucuna ulaşılmıştır. Öğrencilerin kısıtlı miktarda olduğu bilinen kişisel gelirleri ile birlikte değerlendirildiğinde beklenen bir durumu yansıtmaktadır. Dolayısıyla yerel yönetimlerin lojistik desteği sayesinde öğrencilere rahatlıkla ulaşılabileceği gibi uzak mekanların da deneyimlenebilmesinin sağlanabilmesi olasıdır. Böylece kültürel miras değerlerini gelecek kuşaklara aktarmak hususunda halihazırdaki nesli bu konuda donanımlı hale getirmek imkânı ortaya çıkmaktadır.

Literatürde benzer çalışmalarda ücretsiz tanıtım gezileri, ders içeriklerinin kültürel mirası tanıtıcı şeklinde değiştirilmesi, ilgi çekebilecek kısa filmler yapılması, sosyal medya ortamlarının etkin kullanılması vb. öneriler geliştirilmiştir. Önerilerin Şanlıurfa için de geçerliliği bulunmaktadır. Dolayısıyla mevcut öğrencileri eğitsel gezilerle bilgilendirmek hatta mezuniyet törenleri öncesi aileleriyle birlikte deneyim yaşamalarını sağlamak önerilebilir. Gerek temel eğitim düzeyinde gerekse üniversite düzeyinde sosyal bilgiler, sosyal sorumluluk, tarih, halkla ilişkiler derslerinin içerikleri kültürel miras unsurlarıyla zenginleştirilebilir. Bu önerilere ek olarak, panel, sempozyum ve festival gibi etkinlikler düzenlenerek kültürel miras unsurları kamuoyuna tanitılabilir. 
Araştırma bundan sonra yapılacak çalışmalara öncülük etmesi bakımından önemli sayılabilir. Gelecek çalışmalar için aynı konunun ilköğretim ve lise öğrencileri, kentte yaşayan yerel halk örnekleminde ele alınması önerilebilir. Ayrıca soyut kültürel miras unsurlarına olan farkındalık düzeyini ele alan araştırmaların yapılması gerekliliği yadsınamaz bir gerçektir.

\section{KAYNAKÇA}

Abdelazim Ahmed, T. S. (2017). Assessment of students' awareness of the national heritage (Case study: The preparatory year students at the University of Hail, Saudi Arabia). Cogent Social Sciences, 3(1), 1-26. Doi:10.1080/23311886.2017.1306202

Açıc1, F. K., Ertaş, Ş. ve Sönmez, E. (2017). Sürdürülebilir Turizm: Kültür Turizmi ve Kültürel Miras. Akademia Disiplinlerarası Bilimsel Araştırmalar Dergisi, 3(1), 52-66.

Adeniran, A. J. and Akinlabi, F. J. (2011). Perceptions on cultural significance and heritage conservation: A case study of Sussan Wenger's building, Osogbo, Nigeria. African Journal of History and Culture, 3(5), 73-88.

Akkuş, G., Karaca, Ş. ve Polat, G. (2015). Miras farkındalı̆̆ı ve deneyïmï ünïversite öğrencilerïne yönelik keşifsel bïr çalışma. Akademik Bakış Dergisi, Temmuz-A ̆̆ustos (50), 71-81.

Aplin, G. (2007). Heritage as exemplar: a pedagogical role for heritage studies in values education. The Environmentalist, 27(3), 375-383. Doi:10.1007/s10669-007-9053-4

Arıkan, İ. (2012). İlköğretim 7. sınıf öğrencilerinin kültürel miras ile ilgili başarı düzeyleri ve tutumlarının bazı değişkenlerle incelenmesi (Adıyaman Örneği). Adyaman Üniversitesi, Sosyal Bilimler Enstitüsü, Yüksek Lisans Tezi.

Aysu, G. (2013). Kültürel mirasın korunması sürecinin yönetiminde stratejik iletişim yönetiminin yeri. Marmara Üniversitesi, Sosyal Bilimler Enstitüsü, Halkla İlişkiler ve Tanıtım Anabilim Dalı, Halkla İlişkiler Bilim Dalı, Doktora Tezi.

Can, M. (2009). Kültürel Miras ve Müzecilik Çalışma Raporu. Ankara. http://teftis.kulturturizm.gov.tr/Eklenti/1279, muserrefcanpdf.pdf?1 adresinden erişildi. Erişim tarihi: 16.09 .2018

Çetin, T. (2010). Cumalıkızık köyünde kültürel miras ve turizm algısı. Milli Folklor, 22(87), 181190.

Çetin, T. ve Gürgil, F. (2014). Üniversite öğrencilerinin Bartın'ın doğal ve kültürel turizm değerlerine yönelik farkındalıkları. Uşak Üniversitesi Sosyal Bilimler Dergisi, 7(4), 255-274.

Çetin, T., Karakuş, U. ve Aksoy, B. (2012). Yabancı uyruklu öğrencilerin turizm ve Türkiye'nin turizm değerlerine ilişkin algıları. Uşak Üniversitesi Sosyal Bilimler Dergisi, 5(3), 180-196.

Del Barrio, M. J., Devesa, M. and Herrero, L. C. (2012). Evaluating intangible cultural heritage: The case of cultural festivals. City, Culture and Society, 3(4), 235-244. Doi:10.1016/j.ccs.2012.09.002

Demirbulat Güdü, Ö., Saatcı, G. ve Avcıkurt, C. (2015). Bursa'nın somut kültürel varlıklarına yönelik öğrencilerin algıları: Harmancık MYO örneği. Gümüşhane Üniversitesi Sosyal Bilimler Elektronik Dergisi, (12), 62-86.

Dinç, E., Erdil, M. ve Keçe, M. (2011). Uşak Üniversitesi öğrencilerinin tarihi ve kültürel eserler hakkındaki ilgi ve farkındalıkların incelenmesi. Uşak Üniversitesi Sosyal Bilimler Dergisi, 4(2), 267-285.

Durak, S., Yeke, S. T. ve Arslan, T. V. (2016). Significance of cultural heritage preservation in sustainable cultural tourism: Muradiye complex in Bursa, Turkey. European Journal of Sustainable 
Development, 5(4), 1-12. Doi:10.14207/ejsd.2016.v5n4p1

Göğebakan, Y. (2009). Görsel sanatlar ve sosyal bilgiler derslerinin ilişkilendirilmesinin kültür varlıklarını tanıma ve sahip çıkma ile ilgili kazanımların gerçekleşmesi ve öğrencilerin tutumları üzerinde etkileri. Gazi Üniversitesi, Eğitim Bilimleri Enstitüsü, Yüksek Lisans Tezi.

Gümüş, N. ve Özüpekçe, S. (2009). İlköğretim okulu öğrencilerinin turizme yönelik görüşleri: Foça örneği. Dokuz Eylül Üniversitesi Buca Eğitim Fakültesi Dergisi, 25, 25-34.

Güneş, E. ve Alagöz, G. (2018). Turïzm eğitimï alan öğrencilerïn kültürel mïras tutumları üzerïne bïr araştırma. Adıyaman Üniversitesi Sosyal Bilimler Enstitüsü Dergisi, 10(29), 754-777.

Gürgil, F. (2017). Öğretmen adaylarının halk kültürüne yönelik algılarının incelenmesi. Journal of History Culture and Art Research, 6(6), 523-541. Doi:10.7596/taksad.v6i6.1214

Hovater, S. E. (2007). Developing cultural awareness: A grounded theory study of pre-service teachers' field experiences in Taiwan. http://digitalcommons.unl.edu/cehsdisshttp://digitalcommons.unl.edu/cehsdiss/14 adresinden erişildi. Erişim tarihi: 06.10.2018

Ismail, W. H. W. and Nadarajah, J. R. (2016). Young Visitors in the City: Their Perceptions of Heritage Buildings. Procedia-Social and Behavioral Sciences, 234, 470-477. Doi:10.1016/j.sbspro.2016.10.265.

Jaafar, M., Noor, S. M. and Rasoolimanesh, S. M. (2015). Perception of young local residents toward sustainable conservation programmes: A case study of the Lenggong World Cultural Heritage Site. Tourism Management, 48, 154-163. Doi:10.1016/j.tourman.2014.10.018

Jimura, T. (2011). The impact of world heritage site designation on local communities - A case study of Ogimachi, Shirakawa-mura, Japan. Tourism Management, 32(2), 288-296. Doi:10.1016/j.tourman.2010.02.005

Koç, R. ve Akdoğan, H. (2018). Çocuklara değer aktarımının önemi. The Journal of Academic Social Science Studies, 65, 1-16. Doi: 10.9761/JASSS6951

Korumaz, A. G. (2015). Kültürel mirras yönetiminde karar destek sistemlerinin kullanımına yönelik bir model önerisii: Selçuk Üniversitesi Fen Bilimleri Enstitüsü, Mimarlık Ana Bilim Dalı Doktora Tezi.

Kozak, M. (2017). Bilimsel araştırma tasarım yazım ve yayım teknikleri. Ankara: Detay Yayın.

Köroğlu, Ö., Ulusoy Yıldırım, H. ve Avcıkurt, C. (2018). Kültürel miras kavramına ilişkin algıların metafor analizi yoluyla incelenmesi. Turizm Akademik Dergisi, 5(1), 98-113.

Külcü, Ö. T. (2015). Kültürel miras kavramının eğitim açısından önemi. Akademia Disiplinlerarası Bilimsel Araştırmalar Dergisi, 1(1), 27-32.

Nicholas, L. N., Thapa, B. and Ko, Y. J. (2009). Residents' perspectives of a world heritage site. Annals of Tourism Research, 36(3), 390-412. Doi:10.1016/j.annals.2009.03.005

Richards, G. (2018). Cultural tourism: A review of recent research and trends. Journal of Hospitality and Tourism Management, 36, 12-21. Doi:10.1016/j.jhtm.2018.03.005

Selçuk, M. (1999). Teorik ve pratik açmazlarıyla kültürel miras öğretimini sorgulayan bir deneme. Ankara Üniversitesi İlahiyat Fakültesi Dergisi, 39(2), 255-264. Doi:10.1501/Ilhfak_0000001341

Seyhan, B. (2014). Frigya bölgesinin kültürel miras kapsamında değerlendirilmesi. Anadolu Üniversitesi, Sosyal Bilimler Enstitüsü, Turizm ve Otel İşletmeciliği Anabilim Dalı, Yüksek lisans tezi.

Simşek, G. and Elitok Kesici, A. (2012). Heritage education for primary school children through 
drama: The case of Aydın, Turkey. Procedia-Social and Behavioral Sciences, 46, 3817-3824. Doi:10.1016/j.sbspro.2012.06.153

Srivastava, S. (2015). A study of awareness of cultural heritage among the teachers at university level. Universal Journal of Educational Research, 3(5), 336-344. Doi:10.13189/ujer.2015.030505

Şanlıurfa İl Kültür ve Turizm Müdürlüğü. (2018). Şanlıurfa tarihi. Erişim adresi ve tarihi: http://www.urfakultur.gov.tr/TR-65520/tarihce.html. 03.03.2019.

ŞURKAV- Şanlıurfa ili Kültür Eğitim Sanat ve Araştırma Vakfı. http://www.surkav.org.tr/defaultbbdb.html?bs=36. Erişim tarihi: 03.03.2019

Uslu, A. (2016). Kültürel mirasın üç boyutlu modellenmesi ve web ortamında sunulması. Afyon Kocatepe Üniversitesi Fen Bilimleri Enstitüsü, Yüksek lisans tezi.

Uslu, A. ve Kiper, T. (2006). Turizmin kültürel miras üzerine etkileri: Beypazarı/Ankara örneğinde yerel halkın farkındalığı. Tekirdă̆ Ziraat Fakültesi Dergisi, 3(3), 305-314.

Vatan, A. ve Zengin, B. (2015). Söğüt ilçesinde kültürel miras ve yerel halkın turizme bakış açısı. Akademik Sosyal Araştırmalar Dergisi, 3(10), 634-650.

Vehbi, B. O. ve Hoşkara, Ş. Ö. (2009). A model for measuring the sustainability level of historic urban quarters. European Planning Studies, 17(5), 715-739. Doi:10.1080/09654310902778201

Yeşilbursa, C. C. (2011). Sosyal bilgilerde miras eğitiminin öğrencilerin somut kültürel mirasa karşı tutumlarına ve akademik başarılarına etkisi. Gazi Üniversitesi, Eğitim Bilimleri Enstitüsü, İlköğretim Anabilim Dalı, Yüksek Lisans Tezi, Ankara.

Yılmaz Karaca, Ş. ve Şahbudak, E., Akkuş, G. ve Işkın, M. (2017). Kültürel miras farkındalığı: Cumhuriyet Üniversitesi öğrencilerine yönelik bir uygulama çalışması. Akademik Araştırmalar ve Çalışmalar Dergisi, 9(16), 86-100. 